\title{
Sellar Immature Teratoma
}

National Cancer Institute

\section{Source}

National Cancer Institute. Sellar Immature Teratoma. NCI Thesaurus. Code C155809.

An immature teratoma that arises from or adjacent to the sellar region. 